\title{
Impact of the Audit Committee's Characteristics on Voluntary Disclosure: The Case of the Banks Operating in Jordan
}

\author{
Abdullah Majed Al Ma'ani (Corresponding author) \\ Department of Accounting, College of Business School \\ Al-Hussain Bin Talal University, Ma'an, Jordan \\ E-mail: Abdullahmaani87@gmail.com \\ Akram Alawad \\ Department of Economics, College of Business School \\ Al-Hussain Bin Talal University, Ma'an, Jordan
}

Received: December 21, 2018 Accepted: December 26, 2019 Published: December 27, 2019

doi:10.5296/ijafr.v9i4.16143

URL: https://doi.org/10.5296/ijafr.v9i4. 16143

\begin{abstract}
The main objective of this study is to explore the impact of the Audit Committee's characteristics on the level of voluntary disclosure. Regression analysis was applied to verify the hypotheses, where this study used secondary data of 25 banks in the banking sector listed on the Amman Stock Exchange (ASE), for the period 2015 until 2017. The study found that there was an impact of the number of meetings of the Audit Committee on the level of voluntary disclosure, but there were no impacts, for both the size and independence of the Audit Committee, on the level of voluntary disclosure.
\end{abstract}

Keywords: Voluntary disclosure, Audit committee, Jordanian banks

\section{Introduction}

The financial crises and collapses of many companies, despite the efforts of the largest audit companies, led to the loss of users' credibility of financial statements (Khaddash and Sartawi, 2010). Cortez \& Penacerrada (2010) concluded that a corporate governance system would enhance control procedures, thus improving the level of disclosure. 


\section{MInstitute ${ }^{\text {Mink }}$}

International Journal of Accounting and Financial Reporting

ISSN 2162-3082

The Audit Committee is one of the mechanisms of corporate governance that has gained increased interest, where many previous studies indicated the importance of audit committees.

Ho and Wong (2001) concluded that the Audit Committee has an impact on the volume of disclosure in companies, while Mallin (2004) stated that the board of managers establishes a number of committees, including the Audit Committee and the Remuneration Committee , where some of the activities, duties and responsibilities are distributed among these committees.

Kala (2001) mentioned that the Audit Committee has a role in supporting senior management to supervise and ensure the performance of internal control besides enhancing its effectiveness. Jbara (2014) confirmed that the Audit Committee contributes to improving the efficiency and fit of reports and financial statements, to make sound decisions, where increasing disclosure will lead to meeting the needs of users of financial statements.

Due to the importance of the role played by the Audit Committee, the Central Bank of Jordan issued the regulation No (23) in 1971 on corporate governance, which requires that banks operating in Jordan should have an Audit Committee. This study determined the impact of the characteristics of the Audit Committee on voluntary disclosure in the banks operating in Jordan.

\section{Conceptual Framework}

Independent Variables

Audit committee:

Audit committee independence

Audit committee meeting frequency

Audit committee experience

Audit committee size
Dependent Variable

Voluntary Disclosure

\section{Literature Review and Hypotheses Development}

Forker (1992) regarded the audit committee as a tool to improve disclosure and reduce agency conflict, and it is one of the most effective oversight mechanisms. Wan et al., (2010) indicated that agency theory suggests that independent members of audit committees can help senior management monitor agents' activities, reduce benefits of withholding information and increase disclosure levels by the listed companies

Barako et al. (2006) argued that regular meetings of audit committees likely lead to compliance with responsibilities and the monitoring of financial reporting to improve the quality of information that flows between stockholders and directors, where both parties hold unequal levels of information. 


\section{Mll Macrothink}

International Journal of Accounting and Financial Reporting

ISSN 2162-3082

2019, Vol. 9, No. 4

Karamanou and Vafeas (2005) argued that Audit committee that meets more frequently is more likely to effectively accomplish its monitoring role. Patelli and Prencipe (2007) found that Audit committee independence is associated with more voluntary disclosure.

Carcello and Nea (2003) concluded that there is a relationship between the independence of the Audit Committee and disclosure, while there is no relationship between the size of the Audit Committee and disclosure. Zaluki and Hussin (2009) noted that the larger the size and independence of the Audit Committee are, the better the disclosure would be .Accordingly, the following hypotheses are formulated:

H1: There is an impact of Audit Committee's size on the level of voluntary disclosure in the banks.

$\mathrm{H} 2$ : There is an impact of the number of meetings of Audit Committee on the level of voluntary disclosure in the banks.

H3: There is an impact of the independence of $\backslash$ Audit Committee on the level of voluntary disclosure in the banks.

\section{Methodology}

\subsection{Secondary Data}

Secondary data was collected through the annual reports of 25 bank listed on Amman Stock Exchange during 2015 until 2017.

\subsection{Disclosure Index}

In this study the researcher applied the indicator of voluntary disclosure measure by using un weighted approach, where a value of (1) was given if the item was present in the annual report, otherwise a value of ( 0 was given. To obtain the voluntary disclosure level for each bank, the items disclosed are collected and divided by the total number of banks.

\subsection{Independent Variable}

Table 1 shows how to measure independent variables.

Table 1

Number of Audit Committee is measured by using the number of meetings that the audit Meetings committee attends each year

Independence of the Audit A dummy variable is given the value 1 if the committee Committee : generally comprises non-executive members, 0 otherwise

The size of the Audit Measures audit committee size by the number of members Committee: reported in the firm's annual financial reports. 


\section{The Model}

Multiple regression analysis was used to examine the relationship between the characteristics of the Audit Committee and the level of voluntary disclosure. The following model was used:

$$
\mathrm{VD}=\mathrm{B} 0+\mathrm{B} 1 \mathrm{AC}+\mathrm{B} 2 \mathrm{IND}+\mathrm{B} 3 \mathrm{SIZE}+\varepsilon
$$

Where;

$\mathrm{VD}=$ Voluntary Disclosure

$\mathrm{AC}=$ Number of Audit Committee Meetings

IND = Independence of the Audit Committee

SIZE $=$ The size of the Audit Committee

$\varepsilon=$ Error

\section{Results and Discussion}

Table 2. Descriptive statistics analysis

\begin{tabular}{llllll}
\hline & $\mathrm{N}$ & Minimum & Maximum & Mean & Std. Deviation \\
\hline size & 25 & 3.00 & 5.67 & 3.5867 & 61071 \\
\hline meeting & 25 & 4.00 & 13.00 & 6.0800 & 1.76194 \\
\hline independence & 25 & .00 & 1.00 & .8133 & 27352 \\
\hline disclosure & 25 & 59.33 & 86.67 & 74.0800 & 7.05749 \\
\hline
\end{tabular}

Valid N (listwise) $\quad 25$

The above table shows the descriptive statistics of the study variables, we note that the minimum size of the Audit Committee in banks was 3 members and the maximum was almost 6 members. The statistics indicate that the meetings of the Audit Committee at the maximum limit were 13 while the minimum were 4 meetings. The variable of independence of the Audit Committee indicates that $74 \%$ of the banks disclosed the items of voluntary disclosure between59.33\% and $86.67 \%$.

Table 3. Model summary

\begin{tabular}{lllll}
\hline Model & R & R Square & Adjusted R Square & Std. Error of the Estimate \\
\hline 1 & $512 .^{\mathrm{a}}$ & .262 & .156 & 6.48300 \\
\hline
\end{tabular}

Note: a. Predictors: (Constant), inde, size, meet 


\section{Macrothink}

International Journal of Accounting and Financial Reporting

ISSN 2162-3082

Table 3 shows that the determination coefficient is $26.2 \%$, which indicates the extent to which the independent variables (the size, independence and number of meetings of the Audit Committee) affect the level of voluntary disclosure in banks operating in Jordan.

Table 4

\begin{tabular}{llllll}
\hline Variable & $\mathrm{B}$ & Sts. Error & Beta & $\mathrm{t}$ & $\mathrm{SIG}$ \\
\hline size & 0.861 & 2.176 & 0.074 & 0.395 & 0.697 \\
\hline meetings & $-1.978-$ & .759 & $-.494-$ & -2.606 & .016 \\
\hline Independence & $-1.991-$ & 4.892 & $-.077-$ & $-.407-$ & .688 \\
\hline
\end{tabular}

\subsection{Dependent Variable: Voluntary Disclosure}

Table 4 shows that the value of (Beta) of the independent variable, the size of the Audit Committee, does not affect the level of voluntary disclosure, thus the hypothesis is rejected. This result is consistent with the studies of Arafa and Meligi (2013), Magena and Pike (2005) and Sallehuddin (2016).

The variable of independence of Audit Committee members has no effect on the level of voluntary disclosure, where this outcome is inconsistent with the study of Patelli and Prencipe (2007).

There is an impact of the number of Audit Committee meetings on the level of voluntary disclosure in the banks, where this result is consistent with the results of Karamanou and Vafeas (2005) .Accordingly, the hypothesis is accepted that there is an impact of the number of meetings of the Audit Committee on the level of voluntary disclosure.

\section{References}

Barako, D. G., Hancock, P., \& Izan, H. Y. (2006). Factors influencing voluntary corporate disclosure by Kenyan companies. Corporate Governance: An International Review, 14(2), 107-125.

Carcello, J. V., \& Neal, T. L. (2003). Audit committee characteristics and auditor dismissals following "new" going-concern reports. The Accounting Review, 78(1), 95-117.

Cortez, M. A. A., \& Penacerrada, N. T. (2010). Is it beneficial to incur environmental cost? A case study of Toyota motors corporation, Japan. Journal of International Business Research, 9 , 113.

Forker, J. J. (1992). Corporate governance and disclosure quality. Accounting and Business Research, 22(86), 111-124. 


\section{MlMacrothink}

International Journal of Accounting and Financial Reporting

ISSN 2162-3082

2019, Vol. 9, No. 4

Ho, S. S. M., \& Wong, K. S. (2001). A study of the relationship between corporate governance structures and the extent of voluntary disclosure 7. Journal of International Accounting, Auditing and Taxation, 10(2), 139-156.

Hussain, S. H., \& Mallin, C. (2002). Corporate governance in Bahrain. Corporate Governance: An International Review, 10(3), 197-210.

Jubara, S. (2014). The impact of audit committee regulations on performance quality in banks. Ph. D. Thesis, Amman.

Karamanou, I., \& Vafeas, N. (2005). The association between corporate boards, audit committees, and management earnings forecasts: An empirical analysis. Journal of Accounting Research, 43(3), 453-486.

Khadash, A., Aldeen, H., Artawi, A., \& Almuttaleb, A. (2010). The Capability of Sarbanes-Oxley Act in Enhancing the Independence of the Jordanian Certified Public Accountant \& its Impact on Reducing the Audit Expectation Gap: "An Empirical Investigation from the perspectives of Auditors and Institutional Investors". Jordanian Journal in Business Administration, 6(3), 294-316.

Madi, H. K. M. (2012). Audit Committee Effectiveness and Voluntary Disclosure in Malaysia: PRE and Post Introduction of the Revised Malaysian Code on Corporate Governance 2007. Diss. Universiti Utara Malaysia.

Meligi, A. A. (2014). The impact of Corporate Governance on the Efficiency of Value added by a Firm from its Physical Capital and Intellectual Capital Resources. Evidences from Saudi Listed Companies. Journal of Studies and Business Research.

Mohamad, W. I. A. W., \& Sulong, Z. (2010). Corporate governance mechanisms and extent of disclosure: Evidence from listed companies in Malaysia. International Business Research, 3(4), 216.

Patelli, L., \& Prencipe, A. (2007). The relationship between voluntary disclosure and independent directors in the presence of a dominant shareholder. European Accounting Review, $16(1), 5-33$.

\section{Copyright Disclaimer}

Copyright for this article is retained by the author(s), with first publication rights granted to the journal.

This is an open-access article distributed under the terms and conditions of the Creative Commons Attribution license (http://creativecommons.org/licenses/by/4.0/) 